\title{
BIOGEOCHEMICAL CHARACTERISTICS OF EPIPHITIC LICHEN LOBARIA PULMONARIA OF THE BARGUZIN NATURE RESERVE (THE REPUBLIC OF BURYATIA, RUSSIA)
}

\author{
Tatiana BOLSHUNOVA*, Leonid RIKHVANOV, Antonina MEZHIBOR, Lina ZHORNYAK, \\ Natalia BARANOVSKAYA, Ekaterina EREMINA
}

Tomsk Polytechnic University, 634050, Russia, Tomsk, Lenina ave, 2a/5, of. 43

Received 13 February 2017; accepted 29 August 2017

\begin{abstract}
The research is devoted to the investigation of chemical composition of epiphytic lichens Lobaria pulmonaria growing in the territory of the Barguzin Nature Reserve in the Republic of Buryatia (Russia). This reserve is considered as a background area because of its far location from anthropogenic pollution sources. The objective of this research is to assess the chemical composition of lichens of the Barguzin Nature Reserve - one of the background areas in Russia. 9 lichen samples were collected in the summer 2015, in which the concentrations of 67 chemical elements were detected using inductively coupled plasma mass-spectrometry. The research findings were compared with the data for the lichens from the Zabaykalsky National Park and taiga forest in Tomsk region (oil field area). Comparing the reserve area with the taiga area (with anthropogenic load from oil field development), it was detected that the lichens from the Barguzin Nature Reserve had lower concentrations of most chemical elements except $\mathrm{Na}, \mathrm{Mg}, \mathrm{Al}, \mathrm{Si}, \mathrm{P}, \mathrm{K}, \mathrm{Ca}$, and $\mathrm{Ti}$, which contents are 2-16-fold higher in the lichens of the Barguzin Reserve. The concentrations of most chemical elements detected in the lichen samples of the Barguzin Nature Reserve can be used as baseline values while investigating territories with different anthropogenic load.
\end{abstract}

Keywords: lichens, Lobaria pulmonaria, biomonitoring, Barguzin Nature Reserve, background area, concentrations of chemical elements.

\section{Introduction}

The geography of lichen distribution across the globe is rather vast. Among all multicellular organisms, lichens have the most extensive tolerance to different environmental parameters (Bargagli, 1998). The epiphytic lichens growing on the trunks and brunches of trees are sensitive to the chemical composition of environment, including atmospheric air and precipitation, as well as climate change and some other aspects. Such natural conditions as air humidity, lighting intensity and others influence the species composition of lichen associations and their quantitative characteristics. Whereas the epiphytic lichens have no root system, their nutrition is atmospheric and, consequently, their element composition reflects the generalized chemical composition of the atmosphere (Bargagli, 1998). This work observes the use of epiphytic lichens as accumulative biomonitors when conducting biomonitoring projects (Markert, Wünschmann, \& Baltrėnaité, 2012).
The extent of spatial and temporal changes in the element concentrations incoming from anthropogenic (Radomskaya, Radomskij, Yusupov, \& Moiseenko, 2003; Youssef, Markert, Gurbanov, Sevnic, \& Wünschmann, 2014) and natural sources can be detected by the comparison with reference areas or with baseline (background) element values of the same plant species. In this regard, the data of lichen biomonitoring obtained for anthropogenic polluted territories, including oil-extracting regions, regions of metallurgical and mining facilities (Bolshunova, Rikhvanov, \& Mezhibor, 2016), need to be compared with background concentrations of chemical elements in lichens (Bolshunova, Rikhvanov, \& Baranovskaya, 2015).

Choosing the background area, researchers are usually guided by the remoteness of a studied area from the pollution sources. However, the amount of such areas nowadays becomes progressively smaller, and even in the case of absence of anthropogenic impact, there are transboundary transfers of pollutants, which for some regions have more

*Corresponding author. E-mail: BolshunovaTS@gmail.com 
intensive influence than local sources. Moreover, there are natural factors distinguishing the increased regional background for some chemical elements. The vegetation belt types and substrate types effect also on the chemical element composition of lichens (Prussia \& Killinberg, 1991) and it is rather complicated to choose background parameters.

The main objective of this research is to assess the chemical composition of lichens of the Barguzin Nature Reserve - one of the background areas in Russia. The obtained data may be used for comparison of biogeochemical data in the regions with different types of anthropogenic impact.

The research of the reserve territory is especially relevant because the year 2017 was stated as the Year of natural reserves (Presidential edict of the Russian Federation no. 392 from $1^{\text {st }}$ August 2015). Special emphasis is placed to the study of lichen flora in natural reserves, which are unique protected areas. There are investigations on the description of lichens and lichen-indication in the natural reserves "Kuznetsy Alatau", "Bastak", "Utrish", "Imensky", Dzherginskii in the republic of Buryatia and others (Kostryukova, Krupnova, Mashkova, \& Schelkanova, 2017; Skirina, 2015; Urbanavichus \& Urbanavichene, 2015; Baumgertner, 2012; Mashkova, Krupnova, Kostryukova, \& Shcherbina, 2016; Kharpukhaeva \& Urbanavichus, 2006; Zeltyn \& Insarov, 1993 etc.).

Lichen flora of the Barguzin reserve is quite widely studied (Budaeva, 2010, 2014), however we have not met data on the chemical composition of lichens in this region. The Barguzin reserve, being protected state area, needs in constant observation of natural environment, including atmospheric air. The study of elemental composition of epiphytic lichens will allow estimating the environmental quality.

\section{Research object and methods}

There are some natural reserves over the banks of Baikal lake. The Barguzin Nature Reserve was founded in 1916 with the aim of increasing and studying the Barguzin sable population. It was the first state reserve in the Russian Empire (Imetkhenov \& Tulokhonov, 1992) and the establishment of Russia's environmental protection system.

The Barguzin Nature Reserve is located on the northeastern shore of Baikal lake, on the western slopes of the central part of the Barguzin range (Zapovednoe Podlemorye, 2016). The reserve area is 366,870 hectares, including biosoheric polygon of 111,146 hectares (Zapovednoe Podlemorye, 2016). By the reason of sufficient distances from large pollution sources, the reserve territory is used as a background area for the transformation extent assessment of the developed North-East Bai$\mathrm{kal}$ areas affected by anthropogenic impact (Zapovednoe Podlemorye, 2016). According to the monitoring results of the Northern Baikal area, there are no significant trends of anthropogenic origin in the reserve (Aleksandrova, 2006).
The epiphytic lichen samples were collected in 2015 over the territory of the Barguzin Nature Reserve (the Republic of Buryatia). The foliaceous epiphytic lichens Lobaria pulmonaria (L.) Hoffm (Figure 1) were only sampled.

The area of the Lobaria pulmonaria specie in the European part of Russia embraces the zone of taiga (from northern to southern one) and temperate hardwoodbroadleaved forests. A special interest in this lichen specie is aroused due to reduction of its area in last decades because of the negative impact of human activity (clearance of old hardwood and temperate forests, air pollution, fires). This specie is included in the Red Book of Russia ( $2^{\text {nd }}$ category, sensitive specie), as well as in the first edition of the "Red Book of Buryat Autonomous Soviet Socialist Republic" (Budaeva, 2006). The specie is considered as the recognized indicator of old undisturbed and lowdisturbed forests (Urbanavichus \& Urbanavichene, 2003).

The sampling was realized in cedar-pine forest with addition of aspen and birch from the bark of mature trees at height of outstretched arm. Nine samples were taken in total (Figure 2).

The lichens Lobaria pulmonaria dominate, smothering brunches of firs (Budaeva, 2014). The habitats of Lobaria pulmonaria are limited by air pollution; this specie is quite rare in Europe (Giorgio, Luisa, \& Sonia, 2015; Riga-Karandinos \& Karandinos, 1998; Nadyeina, Dymytrova, Naumovych, Postoyalkin, \& Scheidegger, 2014). It is known that over the territory of Western Siberia and the Urals, Lobaria pulmonaria grows in the areas with minimal extent or absence of anthropogenic impact. Its heavy growing in the background area is rather obvious. Regions of L. pulmonaria habitat are confined to forest areas which are less altered under anthropogenic impact and have higher sun lightness comparing with other communities (Ivanova, 2015).

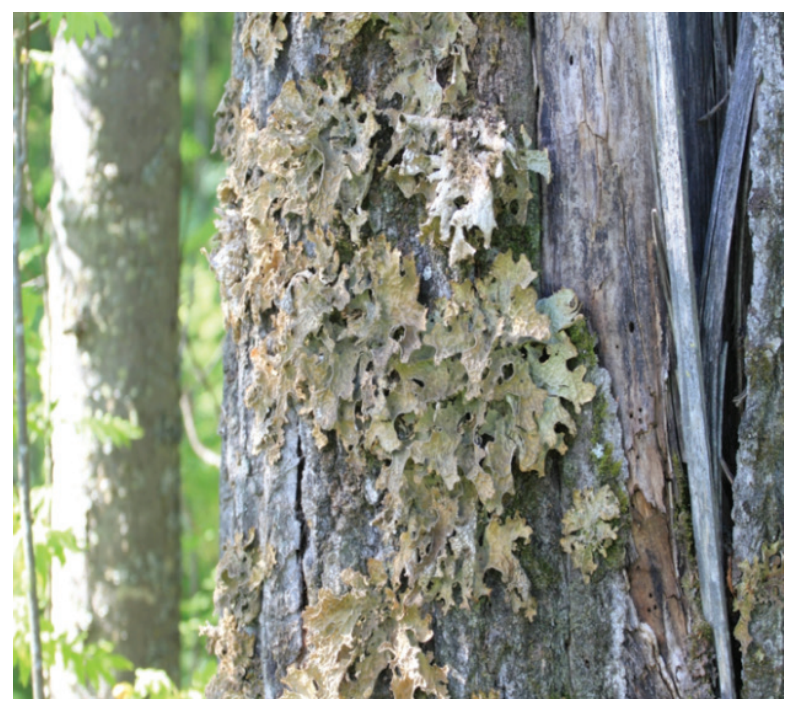

Figure 1. The specie Lobaria pulmonaria (Photo by J. Noskov) 


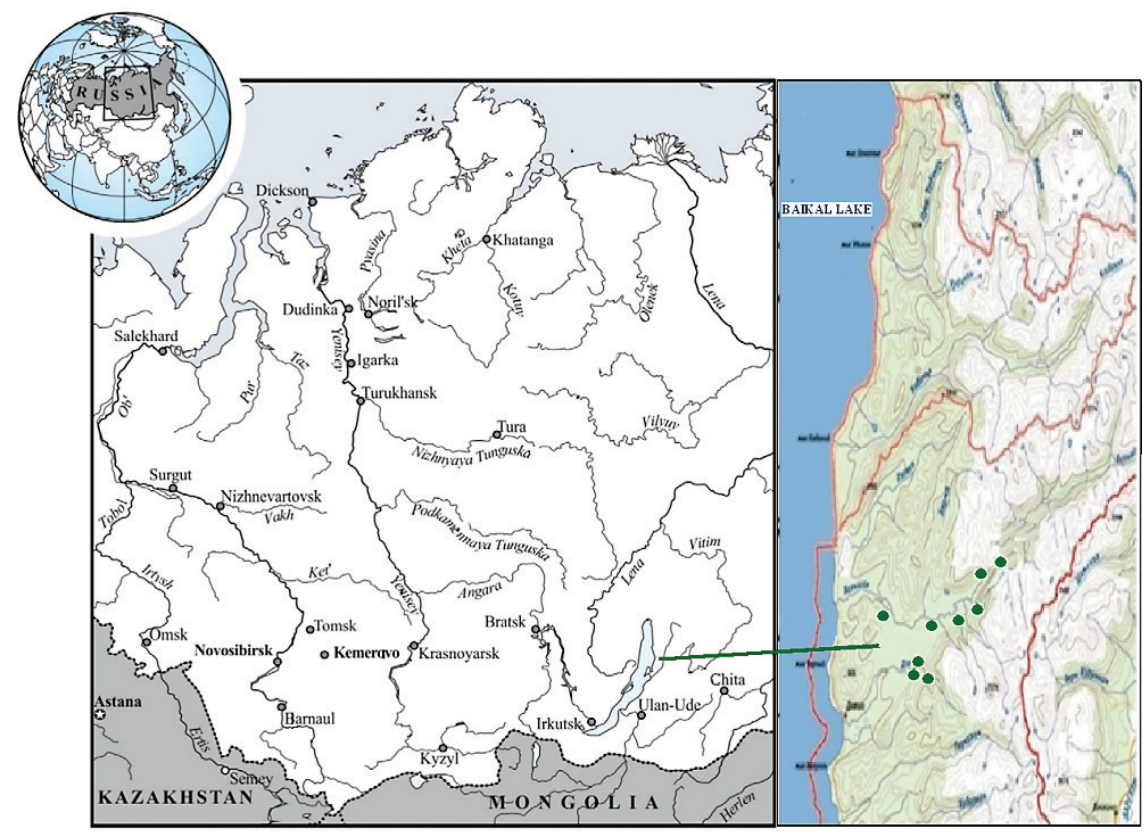

Figure 2. The base map of lichens sampling fields in the Barguzin Nature Reserve

The results of lichenological research of L. pulmonaria in the Utrish reserve allowed increasing the number of reserves in Russia, where this specie grows, up to 55 (excluding Zhigulevsky reserve) (Urbanavichus \& Urbanavichene, 2015).

To compare the results obtained, the data of chemical composition of the same lichen species, sampled in the oil field areas in Tomsk region (Bolshunova, Rikhvanov, \& Mezhibor, 2014), were used. Moreover, we used the information on the concentrations of chemical elements in the epiphytic lichen Evernia mesomorpha (Flot.) Nyl. from the cross-border region - Zabaykalsky National Park (Bolshunova et al., 2015), which together with the Barguzin reserve is on the list of the specially protected areas of Russia. The park was organized in 1986 for protecting unique natural complex of the Baikal lake basin. It occupies the eastern coast of Baikal lake with the peninsula Svyatoy Nos (Budaeva, 2014).

The collected samples were dried until air-dry condition in the laboratory. In order to achieve the uniform distribution of the chemical elements within the samples, they were grinded by the electrical grinder with stainless cover. The concentrations of 67 chemical elements in the lichens were determined by the modern high-sensitivity method -inductively coupled plasma mass-spectrometry (ICP-MS), This method is characterized by low detection limit that is especially important for the biogeochemical investigations (Yusupov \& Karpenko, 2016). The analysis was conducted in the certified chemical-analytical centre "Plasma" in Tomsk, Russia.

\section{Results and discussion}

The obtained data of the chemical composition of the epiphytic lichens Lobaria pulmonaria from the Barguzin
Nature Reserve are presented in Table 1 and Figure 3. The data represent information on 56 chemical elements. Some elements are not represented in the table (Re, Os, Ir, $\mathrm{Pt}, \mathrm{Au}$ and others) due to their low concentrations, which were below the detection limit.

The scatter of the chemical elements concentrations grouped in the s-elements, p-elements, main d-elements, rare d-elements, f-elements in the lichen samples from the Barguzin Nature is presented at Figure 3. The plot at Figure 3 describes the quartile distribution of element concentrations (includes min, max, median). The element distributions show the essential scatter of the main and rare elements (c), as well as $\mathrm{Ba}, \mathrm{Sb}, \mathrm{Mn}, \mathrm{U}$. These results may testify on different accumulation extent in regard to these elements. More illustrative analysis of the elements accumulation in the lichens from two reserves of Baikal lake surroundings may be done through the correlation of the analytical results shown at Figure 4.

The increased concentrations of $\mathbf{N a}, \mathrm{Ca}, \mathrm{Cr}, \mathrm{Fe}, \mathbf{R b}$ (1.5 - 8-fold) and As - 32-fold are detected in the lichens of the Barguzin Nature Reserve. The Lichens of the Zabaykalsky National Park (the investigation was carried out by the instrumental neutron activation analysis, included 28 chemical elements) are characterized by the increased values of $U, T h$, and rare-earth elements (REE). This feature is determined by the specificity of highly-radioactive granitic substrate of the sampling area (Barguzin-Chivyrkuysky land bridge of Baykal lake) (Bolshunova et al., 2015).

Atmospheric fallouts enter the lichens either in liquid state (precipitations), or in dry one due to aerosol sedimentation. Moreover, mineral substances may enter the lichens in the form of dust which contains many chemical elements. The soils of the Barguzin-Chivyrkuysky land bridge are predominantly channery, easy-washed by 
Table 1. Geochemical characteristic of the lichen samples from the Barguzin Nature Reserve (dry matter, mg/kg, $\mathrm{n}=9$ )

\begin{tabular}{|c|c|c|c|c|c|c|c|c|c|c|c|}
\hline 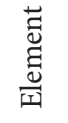 & Mean & St. error & SD & Min & $\operatorname{Max}$ & 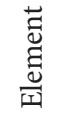 & Mean & St. error & SD & Min & $\operatorname{Max}$ \\
\hline $\mathrm{Li}$ & 0.30 & 0.03 & 0.09 & 0.18 & 0.44 & $\mathrm{Cd}$ & 0.135 & 0.033 & 0.098 & 0.035 & 0.363 \\
\hline B & 7.88 & 0.82 & 2.46 & 2.10 & 10.24 & Sn & 0.084 & 0.009 & 0.026 & 0.053 & 0.133 \\
\hline $\mathrm{Na}$ & 102 & 10 & 29 & 56 & 150 & $\mathrm{Sb}$ & 0.0429 & 0.0066 & 0.0197 & 0.0065 & 0.0784 \\
\hline $\mathrm{Mg}$ & 570 & 47 & 141 & 405 & 840 & Cs & 0.163 & 0.031 & 0.093 & 0.057 & 0.295 \\
\hline $\mathrm{Al}$ & 505 & 56 & 167 & 228 & 800 & $\mathrm{Ba}$ & 35.7 & 5.9 & 17.8 & 4.3 & 61.4 \\
\hline $\mathrm{Si}$ & 927 & 110 & 330 & 456 & 1477 & $\mathrm{La}$ & 0.22 & 0.02 & 0.07 & 0.11 & 0.33 \\
\hline $\mathrm{P}$ & 1949 & 235 & 705 & 1217 & 3450 & $\mathrm{Ce}$ & 0.41 & 0.05 & 0.14 & 0.24 & 0.63 \\
\hline $\mathrm{K}$ & 5148 & 315 & 944 & 4384 & 7459 & $\mathrm{Pr}$ & 0.047 & 0.005 & 0.015 & 0.028 & 0.069 \\
\hline $\mathrm{Ca}$ & 2571 & 293 & 879 & 859 & 3745 & $\mathrm{Nd}$ & 0.17 & 0.02 & 0.06 & 0.09 & 0.29 \\
\hline $\mathrm{Sc}$ & 0.25 & 0.03 & 0.09 & 0.09 & 0.39 & $\mathrm{Sm}$ & 0.032 & 0.003 & 0.010 & 0.018 & 0.048 \\
\hline $\mathrm{Ti}$ & 131 & 19 & 57 & 86 & 267 & $\mathrm{Eu}$ & 0.007 & 0.001 & 0.002 & 0.004 & 0.011 \\
\hline $\mathrm{V}$ & 0.95 & 0.10 & 0.30 & 0.49 & 1.54 & Gd & 0.033 & 0.004 & 0.011 & 0.020 & 0.054 \\
\hline $\mathrm{Cr}$ & 5.0 & 0.4 & 1.1 & 3.6 & 7.2 & $\mathrm{~Tb}$ & 0.0046 & 0.0005 & 0.0015 & 0.0027 & 0.0067 \\
\hline $\mathrm{Mn}$ & 84 & 22 & 66 & 17 & 218 & Dy & 0.024 & 0.003 & 0.009 & 0.014 & 0.041 \\
\hline $\mathrm{Fe}$ & 301 & 29 & 88 & 171 & 453 & Ho & 0.0044 & 0.0006 & 0.0017 & 0.0021 & 0.0075 \\
\hline Co & 0.27 & 0.03 & 0.08 & 0.18 & 0.36 & Er & 0.012 & 0.001 & 0.004 & 0.006 & 0.019 \\
\hline $\mathrm{Ni}$ & 0.82 & 0.09 & 0.28 & 0.42 & 1.39 & $\mathrm{Tm}$ & 0.002 & 0.000 & 0.001 & 0.001 & 0.003 \\
\hline $\mathrm{Cu}$ & 5.9 & 0.4 & 1.3 & 4.2 & 8.3 & $\mathrm{Yb}$ & 0.010 & 0.001 & 0.004 & 0.005 & 0.017 \\
\hline $\mathrm{Zn}$ & 46.1 & 2.4 & 7.3 & 35.1 & 55.4 & $\mathrm{Lu}$ & 0.002 & 0.000 & 0.001 & 0.001 & 0.003 \\
\hline $\mathrm{Ga}$ & 0.18 & 0.02 & 0.06 & 0.10 & 0.28 & Hf & 0.014 & 0.002 & 0.005 & 0.007 & 0.022 \\
\hline As & 0.44 & 0.05 & 0.15 & 0.29 & 0.77 & $\mathrm{Ta}$ & 0.007 & 0.001 & 0.003 & 0.004 & 0.011 \\
\hline $\mathrm{Rb}$ & 17.6 & 3.0 & 9.0 & 5.4 & 31.4 & W & 0.040 & 0.004 & 0.012 & 0.022 & 0.058 \\
\hline $\mathrm{Sr}$ & 18.3 & 2.3 & 6.9 & 9.4 & 30.0 & $\mathrm{Hg}$ & 0.058 & 0.006 & 0.019 & 0.031 & 0.085 \\
\hline Y & 0.12 & 0.01 & 0.04 & 0.06 & 0.20 & $\mathrm{Tl}$ & 0.015 & 0.004 & 0.011 & 0.005 & 0.033 \\
\hline $\mathrm{Zr}$ & 0.78 & 0.09 & 0.28 & 0.38 & 1.24 & $\mathrm{~Pb}$ & 1.23 & 0.19 & 0.57 & 0.72 & 2.32 \\
\hline $\mathrm{Nb}$ & 0.09 & 0.01 & 0.03 & 0.05 & 0.14 & $\mathrm{Bi}$ & 0.051 & 0.005 & 0.014 & 0.028 & 0.073 \\
\hline Mo & 0.11 & 0.04 & 0.12 & 0.04 & 0.44 & Th & 0.065 & 0.008 & 0.025 & 0.034 & 0.112 \\
\hline $\mathrm{Ag}$ & 0.012 & 0.002 & 0.005 & 0.006 & 0.021 & $\mathrm{U}$ & 0.036 & 0.010 & 0.029 & 0.014 & 0.107 \\
\hline
\end{tabular}

St. error - Standard error; SD - Standard deviation

precipitations and wind-moving in case of vegetation absence. Thus, high concentrations of chemical elements can be explained by the weathering and transportation of tiny particles of soil and bedding rocks, as well as water drops, and their capture and absorption by the lichens.

Anomalously low As concentrations were found in the lichens from the Zabaykalsky National Park (BarguzinChivyrkuysky land bridge) comparing the As concentrations in the lichens from the Barguzin reserve (32-fold lower) and with other regions which were studied by us earlier (Table 2).

When analyzing Table 2 we observe that the As concentration in the lichens of the Barguzin Nature Reserve is close to the values of other territories. Regarding low As concentrations in the lichens of the Barguzin-Chivyrkuysky land bridge, which is observed also as a background region without anthropogenic impact, they may be explained by local geological features. Barguzin-Chivyrkuysky land bridge is composed by Pliocene-Eopleistocene relatively young sediments, and the Barguzin Reserve area is composed by ancient, predominantly granitoid rock complexes. The specificity of the Barguzin-Chivyrkuysky land bridge of low As concentrations is confirmed by the research of poplar leaf in this area. The ordered series of chemical elements by the value of concentration factor in poplar leaf ash from the Ust-Bargusin (Zabaykalsky National Park) looks as the following range: $\mathrm{Ca}-\mathrm{La}-\mathrm{Br}-\mathrm{Rb}-\mathrm{Th}-\mathrm{Ag}-\mathrm{Sm}-\mathrm{Cs}-$ Fe-Co-Hf-Na-Eu-Zn-Ba-Nd-Sr-Lu-Ta-Sc-Ce-Cr-Tb-U$\mathrm{Sb}-\mathrm{Au}-\mathrm{Yb}-\underline{A s}$ (in decreasing order) (Yusupov, Rikhvanov, Baranovskaya, \& Yalaltdinova, 2016).

Analyzing the above information, the area of the Barguzin-Chivyrkuysky land bridge can be observed as an ideal natural background of As in the complex of biosubstrates. 


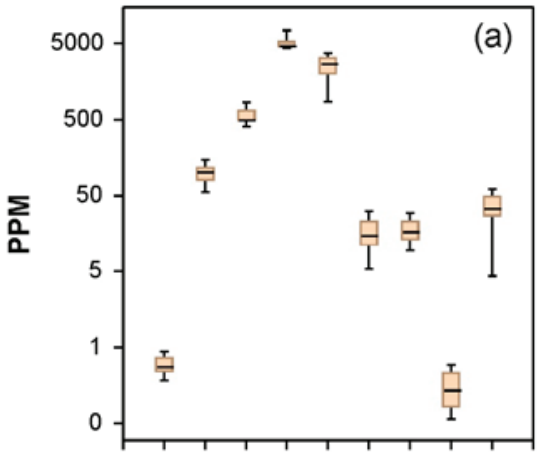

Li $\mathrm{NaMg} \mathrm{K} \mathrm{Ca} \mathrm{Rb} \mathrm{Sr} \mathrm{Cs} \mathrm{Ba}$

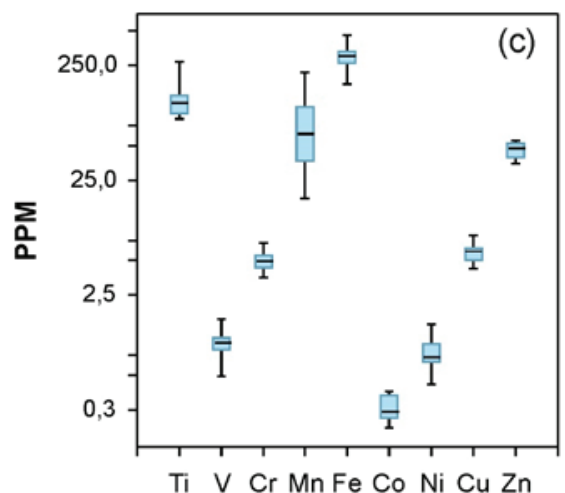

$\mathrm{Ti} \mathrm{V} \mathrm{Cr} \mathrm{MnFe} \mathrm{Co} \mathrm{Ni} \mathrm{Cu} \mathrm{Zn}$

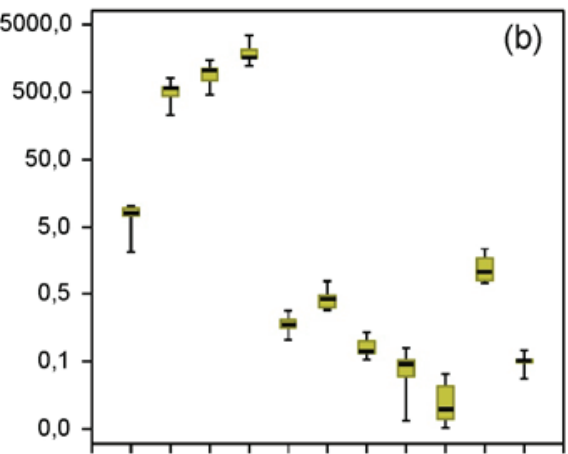

B Al Si P GaAs Sn Sb TI Pb Bi

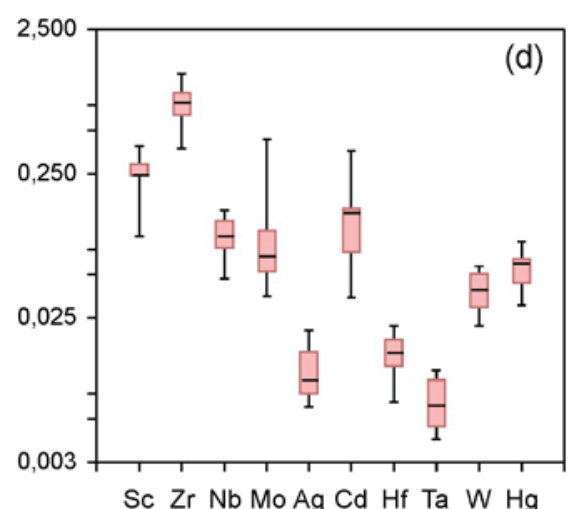

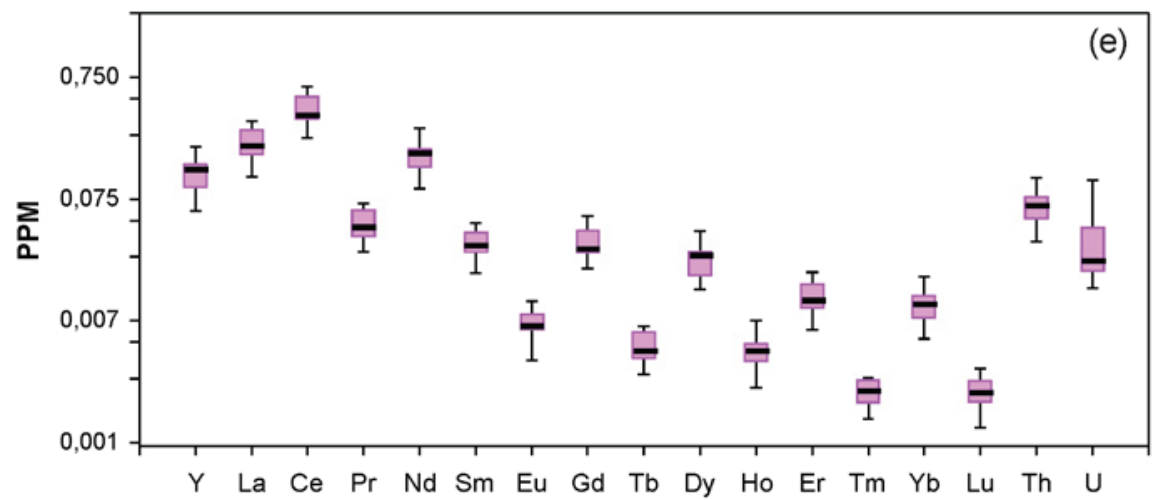

Figure 3. Box\&Whisker plot of the s-elements (a), the p-elements (b), the main d-elements (c), the rare d-elements (d), the f-elements (e) in the lichen samples Lobaria pulmonaria from the Barguzin Nature (includes min, max, median, 25- and 75- percentiles of the values)

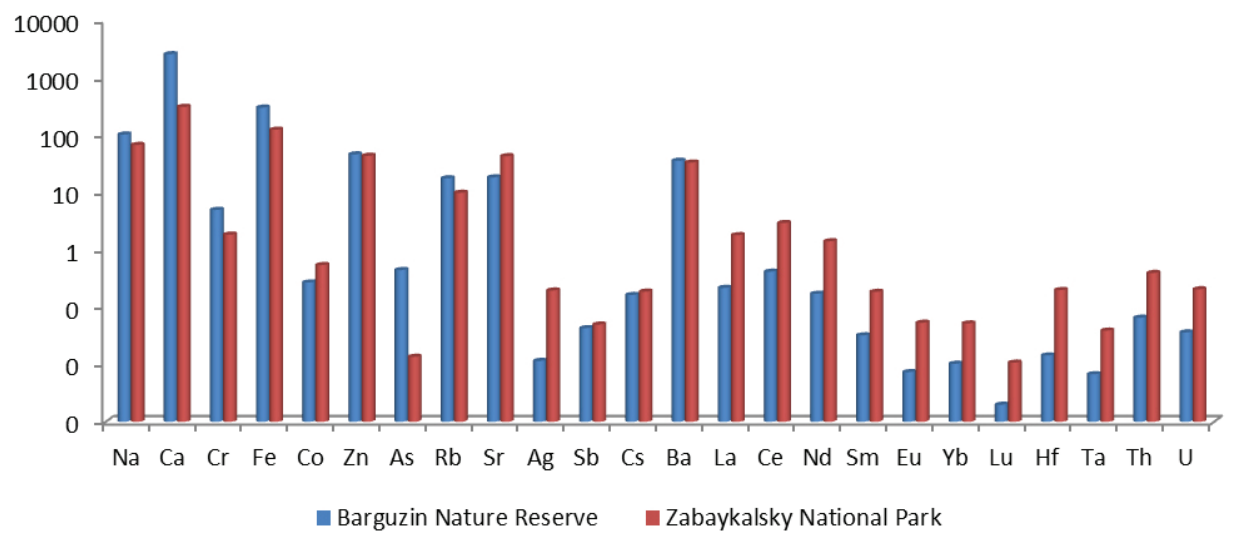

Figure 4. Concentrations of some chemical elements $(\mathrm{mg} / \mathrm{kg})$ in the lichens of the Barguzin Nature Reserve and the Zabaykalsky National Park (Bolshunova et al., 2015) logarithmic scale 
Table 2. Mean As concentrations in the lichens of background and anthropogenically-changed regions, $\mathrm{mg} / \mathrm{kg}$

\begin{tabular}{|c|c|c|c|c|c|c|}
\hline $\begin{array}{c}\text { Tomsk oblast } \\
\text { (Bolshunova } \\
\text { et al., 2015) }\end{array}$ & $\begin{array}{c}\text { Background } \\
\text { regions } \\
\text { (Bargagli, } \\
1998)\end{array}$ & $\begin{array}{c}\text { Kemerovo } \\
\text { oblast } \\
\text { (Bolshunova } \\
\text { et al., 2015) }\end{array}$ & $\begin{array}{c}\text { Barguzin-Chivyrkuysky } \\
\text { land bridge } \\
\text { (Bolshunova et al., } \\
2015)\end{array}$ & $\begin{array}{c}\text { Petroleum extraction } \\
\text { regions, Tomsk oblast } \\
\text { (Bolshunova et al., 2014) }\end{array}$ & $\begin{array}{c}\text { Regions of } \\
\text { northern } \\
\text { Eurasia } \\
\text { (Bolshunova } \\
\text { et al., 2014) }\end{array}$ & $\begin{array}{c}\text { Barguzin } \\
\text { Nature } \\
\text { Reserve }\end{array}$ \\
\hline 0.34 & $0.3-1.5$ & 0.44 & 0.013 & 0.19 & 0.26 & 0.44 \\
\hline
\end{tabular}

Because of the rare distribution of Lobaria pulmonaria not only in Russia, but also in Europe, the data on the concentrations of a wide range of chemical elements in the scientific literature are difficult to find. The information on the elements accumulation in the lichens Lobaria pulmonaria sampled in the oil field territories in Tomsk region (Bolshunova et al., 2014) and investigated area of the Barguzin Nature Reserve is presented at the round chart (Figure 5). It should be especially mentioned that the element concentration analysis in the lichens of one species is conducted using ICP-MS.

Estimating the round chart, it is interesting to outline that the concentrations of macronutrients $\mathrm{Na}, \mathrm{Mg}, \mathrm{Al}, \mathrm{Si}$, $\mathrm{P}, \mathrm{K}, \mathrm{Ca}$, and Ti are 2-16-fold higher in the lichens of the Barguzin Reserve as compared with the lichens of the oil field area. The main sources of these elements in the lichens are likely both soil transfer and wet aerosol transfer from Baykal Lake area. There are also 10-fold exceeding of $\mathrm{Ta}$ and 2-fold exceeding of $\mathrm{Sr}$ and $\mathrm{Ba}$ registered in the lichens of the Barguzin Reserve. According to (KabataPendias \& Pendias, 1992), essential elements, particularly $\mathrm{Ca}, \mathrm{Mg}, \mathrm{P}, \mathrm{K}$ are antagonistic elements for the absorption and metabolism of many trace elements, and, conversely, trace elements can inhibit macro-components absorption.

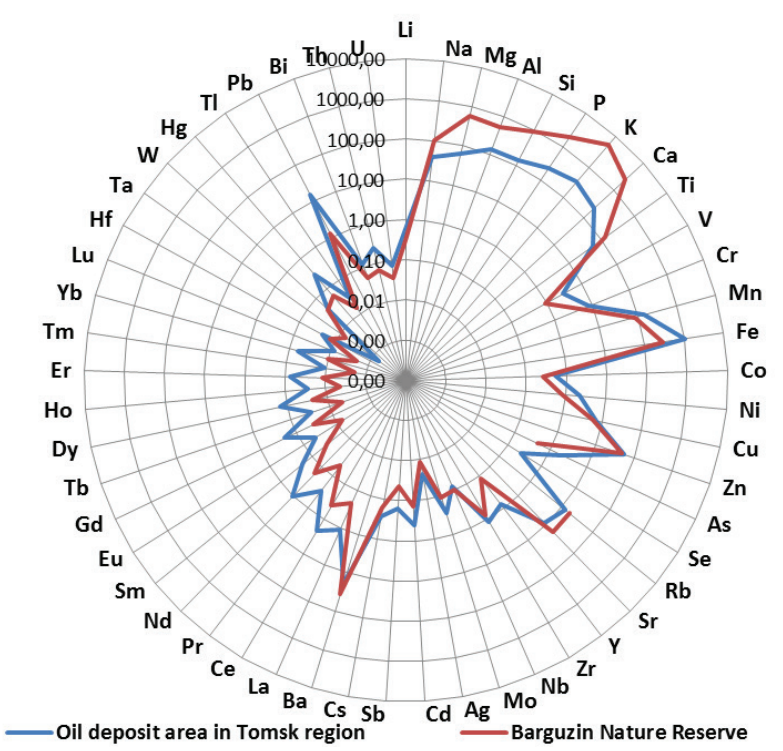

Figure 5. Concentrations of chemical elements in the lichens Lobaria pulmonaria of the Barguzin Reserve and in oil field area in Tomsk region (according to the data Bolshunova et al., 2014)

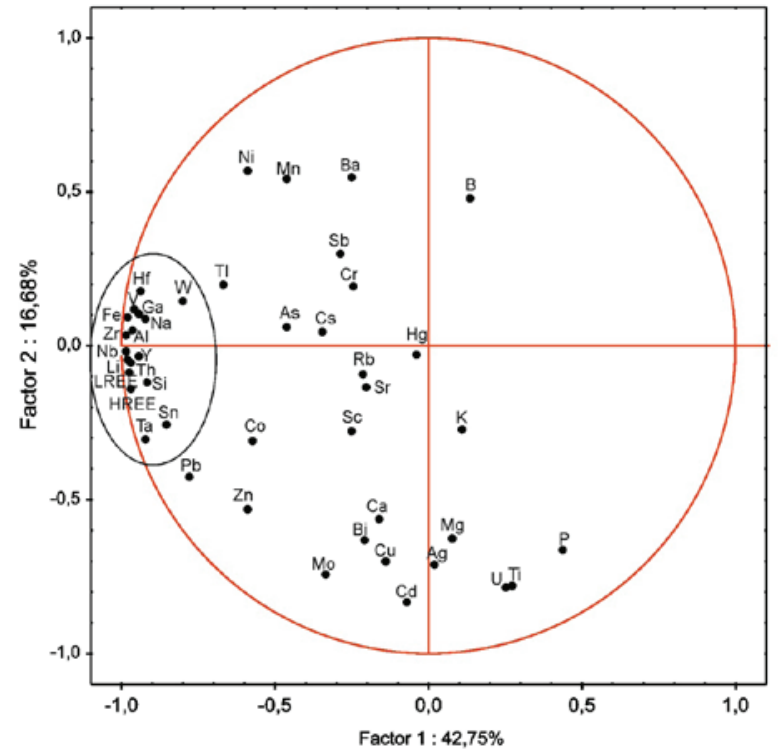

Figure 6. Chart of factor analysis. LREE - light rare-earth elements, HREE - heavy earth elements

Most of the chemical elements, including rare-earth elements and heavy metals ( $\mathrm{Hg}, \mathrm{Fe}, \mathrm{Mn}, \mathrm{Cd}, \mathrm{Sb}, \mathrm{As}$ ), which reflect the specificity of the oil production, have higher accumulation levels in the lichens of Tomsk region: 2-12-fold. The similar $\mathrm{Zn}$ concentration in the lichens of the Barguzin Reserve, the Zabaykalsky National Park and anthropogenically changed area in Tomsk region were registered - 48 $\mathrm{mg} / \mathrm{kg}$ on the average for three areas. These results are probably determined by high zinc biophility and its important role for the metabolism of lichens (Bargagli, 1998).

That to determine the main sources of the chemical elements input in the lichens we carried out the analysis of possible factors defining the elements accumulation. The results of the factor analysis (Figure 6) show two main factors (43 and 17\%), other factors are less than $10 \%$.

The factor analysis exposed a large association of lithophile elements, including rare-earth ones (the second factor $16.68 \%$ ). Their input in the lichens is probably connected with the soil particles transportation. The first factor $(42.75 \%)$ does not determine stable associations, $\mathrm{U}-\mathrm{Ti}$ association is only isolated, being rock component probably connected with the transport of particles from the nearby Barguzin-Chivyrkuysky land bridge of Baykal Lake (Zabaykalsky National Park). Among elements of the first factor, $\mathrm{K}, \mathrm{P}$, and $\mathrm{Mg}$ are outlined. These elements reflect absorption by the lichens of aerosols from the lake. 


\section{Conclusions}

1. Estimating the biogeochemical peculiarities of the lichens of the Barguzin Nature Reserve, we can conclude that this area is less exposed to the anthropogenic influence and has no strongly pronounced structural features of the underlying rocks structure.

2. Comparing to the lichens of the Zabaikalsky National Park and the oil field area in Tomsk region, the lichens of the Barguzin reserve are characterized by lower accumulation of a majority of chemical elements, including rare, radioactive ones and heavy metals. At the same time the concentrations of $\mathrm{Na}, \mathbf{M g}, \mathrm{Al}, \mathrm{Si}, \mathrm{P}, \mathrm{K}, \mathrm{Ca}$, and Ti are from 2 to 16-fold higher than those in the lichens from the oil field area. This fact is probably determined by soil particles transportation (in relation to lithophile elements), as well as the transfer of aerosols from Baikal lake, the waters of which contain high concentrations of $\mathrm{Ca}, \mathrm{Na}, \mathrm{Mg}, \mathrm{K}, \mathrm{Si}$, and P. However, the fact of the presence of this rare lichen specie, growing abundantly in the reserve, tells us about pure atmospheric air.

3. As a whole, the concentrations of most chemical elements in the lichens from the Barguzin reserve can be used as background values for while studying anthropogenically disturbed areas, including mining and dressing facilities.

The obtained data on the elemental composition of lichens Lobaria Pulmonaria are possible to consider as a natural background and use for biogeochemical monitoring in natural and urbanized landscapes in the Baikal lake area. The results may be observed as reference data in the environmental protection perspective when estimating the extent of anthropogenic impact in different regions of the northern hemisphere.

\section{Acknowledgments}

This work was supported by the Russian Scientific Foundation grant № 15-17-10011.

\section{References}

Aleksandrova, I. (2006). Monitoring of pollution of the North Baikal region. Ulan-Ude: Zebra (in Russian).

Bargagli, R. (1998). Trace elements in terrestrial plants: an ecophysiological approach to biomonitoring and biorecovery. Springer.

Baumgertner, M. (2012). Lichens and lichen-indication of the State Natural Reserve "Kuznetsky Alatau". Problems of Regional Ecology, 1, 53-57 (in Russian).

Bolshunova, T., Rikhvanov, L., \& Mezhibor, A. (2014). Epiphytic lichens as indicators of air pollution in Tomsk Oblast (Russia). IOP Conference Series: Earth and Environmental Sciences, 21, 012043. https://doi.org/10.1088/1755-1315/21/1/012043

Bolshunova, T., Rikhvanov, L., \& Baranovskaya, N. (2015). On the issue of choosing the background concentrations of chemical elements in epiphytic lichens. Bulletin of the Tomsk Polytechnic University, 326, 33-46 (in Russian).

Bolshunova, T., Rikhvanov, L., \& Mezhibor, A. (2016). Assessment of the tailing impact on the environment according to the study of the epiphytic lichens (the case of Komsomolsk and Ursk tailings, Kemerovo region, Russia). International Multidisciplinary Scientific GeoConference Surveying Geology and Mining Ecology Management, SGEM 16th. Ecology, Economics, Education and Legislation, Conference proceedings, 5(II), 125-132.

Budaeva, S. (2006). Monitoring of rare lichen species of the Barguzin Nature Reserve History and current situation of specially protected natural territories of the Baikal region. Materials of the Region Scientific-Practical Conference Devoted to the 90th Anniversary of Reserve Management in Russia Ulan-Ude (pp. 80-81) (in Russian).

Budaeva, S. (2014). Lichens of the northeastern Baikal region. Proceedings of Russian Academy of Samara Scientific Center of Sciences, 16(5), 1581-1586 (in Russian).

Budaeva, S. (2010). Lichens of the blood line Nephromataceae in the flora of the State Natural Biosphere Reserve "Barguzinsky". Proceedings of the Tigireksky reserve, 3, 128-129 (in Russian).

Giorgio, B., Luisa, F., \& Sonia, R. (2015). Structural variables drive the distribution of the sensitive lichen Lobaria Pulmonaria in Mediterranean old-growth forests. Ecological Indicators, 53, 37-42. https://doi.org/10.1016/j.ecolind.2015.01.023

Imetkhenov, A., \& Tulokhonov, A. (1992). Specially protected natural areas of Buryatia (Ulan-Ude) (pp. 152) (in Russian).

Ivanova, N. (2015). Factors limiting distribution of the rare lichen species Lobaria pulmonaria (in forests of the Kologriv Forest Nature Reserve). Biology Bulletin, 42(2), 145-153 (in Russian). https://doi.org/10.1134/S1062359015020041

Kabata-Pendias, A., \& Pendias, H. (1992). Trace metals in soils and plants. Boca Raton: CRC Press.

Kharpukhaeva, T., \& Urbanavichus, G. (2006). New and rare lichen species from Republic of Buryatia (Dzherginskii Nature Reserve). Journal of botany, 91(11), 1744-1749 (in Russian).

Kostryukova, A., Krupnova, T., Mashkova, I., \& Schelkanova, E. (2017). Monitoring air quality using lichens in Chelyabinsk, Russian Federation. International Journal of GEOMATE, 12(34), 101-106. https://doi.org/10.21660/2017.34.2717

Markert, B., Wünschmann, S., \& Baltrènaite, E. (2012). Innovative observation of the environment. Bioindicators and biomonitors: definitions, strategies and applications. Journal of Environmental Engineering and Landscape Management, 20(3), 221239. https://doi.org/10.3846/16486897.2011.633338

Mashkova, I., Krupnova, T., Kostryukova, A., \& Shcherbina, A. (2016). Lichen monitoring of air pollution in south parts of Ilmen state reserve. International Multidisciplinary Scientific GeoConference Surveying Geology and Mining Ecology Management, SGEM 16th, Bulgaria, 3, 563-571.

Nadyeina, O., Dymytrova, L., Naumovych, A., Postoyalkin, S., \& Scheidegger, C. (2014). Distribution and dispersal ecology of Lobaria Pulmonaria in the largest primeval beech forest of Europe. Biodiversity and Conservation, 23(13), 3241-3262. https://doi.org/10.1007/s10531-014-0778-3

Prussia, C., \& Killinberg, K. (1991). Concentrations of ten elements in two common foliose lichens: leachability, seasonality and the influence of rock and tree bark substrates. Bryologist, 94, 135-142. https://doi.org/10.2307/3243688

Radomskaya, V., Radomskij, S., Yusupov, D., \& Moiseenko, V. (2003). Bioaccumulation of noble metals in plants. Doklady Akademii Nauk, 388(1), 34-37 (in Russian).

Riga-Karandinos, A., \& Karandinos, M. (1998). Assessment of air pollution from a lignite power plant in the plain of Megalopolis (Greece) using as biomonitors three species of lichens, 
impact on some biochemical parameters of lichens. The Science of the Total Environment, 215(1-2), 167-183. https://doi.org/10.1016/S0048-9697(98)00119-3

Skirina, I. (2015). Lichen list of "Bastak" natural reserve. Biodiversity and Environment Of Far East Reserves, 4, 28-87 (in Russian).

Urbanavichus, G., \& Urbanavichene, I. (2015). The protected lichen species listed the red book of Russia in nature reserve "Utrish». Scientific proceedings of the State Natural Reserve "Priursky", 30(1), 253-255 (in Russian).

Urbanavichus, G., \& Urbanavichene, I. (2003, May). Lobaria Pulmonaria (L.) Hoffm. in Volzhsko-Kamsky reserve (the Republic Tatarstan). Protection of Vegetation and Animals of the Povolzhieand Surrounding Territories: proceedings of All-Russian scientific conference, Penza (pp. 134-136) (in Russian).

Yusupov, D., Rikhvanov, L., Baranovskaya, N., \& Yalaltdinova, A. (2016). Geochemical features of poplar leaf elemental composition in urban areas. Bulletin of the Tomsk Polytechnic University Geo Assets Engineering, 327(6), 25-36 (in Russian).
Yusupov, D., \& Karpenko, Yu. (2016). REE, Uranium (U) and Thorium (Th) contents in Betula pendula leaf growing around Komsomolsk gold concentration plant tailing (Kemerovo region, Western Siberia, Russia). IOP Conference Series: Earth and Environmental Science, 43(1), 012053. https://doi.org/10.1088/1755-1315/43/1/012053

Zeltyn, S., \& Insarov, G. (1993). Data base of background monitoring of epiphytic lichens. Problems of Environmental Monitoring and Ecosystem Modeling 15, Sankt-Petersburg (pp. 244262) (in Russian).

Youssef, N., Markert, B., Gurbanov, E., Sevnic, H., \& Wünschmann, S. (2014). Bioindication of trace metal pollution in the atmosphere of Baku city using ligustrum japonicum, olea europea, and pyracantha coccinea leaves. Journal of Environmental Engineering and Landscape Management, 22(1), 14-20. https://doi.org/10.3846/16486897.2013.804828

Zapovednoe Podlemorye. (2016). Retrieved from http://zapovednoe-podlemorye.ru 